Full-text Available Online at www.bioline.org.br/ja
J. Appl. Sci. Environ. Manage. June, 2007

Vol. 11 (2) 223 - 229

\title{
Source and Sink Strength of Carbon Dioxide, Methane and Distribution of Sulfate in Salt-marsh Soils at the Wadden Sea Coast of Northern Germany
}

\section{.${ }^{1}$ KHAN, MD. HARUNOR RASHID $;{ }^{2}$ HANS-PETER BLUME; ${ }^{1}$ TADASHI ADACHI; ${ }^{3}$ ULRICH PFISTERER; ${ }^{3}$ UDO MÜLLER-THOMSEN}

\author{
${ }^{1}$ Department of Environmental Management Engineering, Faculty of Environmental Science and Technology, Okayama University, \\ Okayama 700-8530, Japan.Email: duharun@yahoo.com ${ }^{2}$ Institute for Plant Nutrition and Soil Science, University of Kiel, 24105 Kiel, \\ Germany. ${ }^{3}$ Division of Soil Ecology, Res. and Tech. Center-West Coast, 25761 Büsum, Univ. of Kiel, Germany.
}

\begin{abstract}
A field study was conducted at Schleswig-Holstein of Kiel in Germany to evaluate the factors controlling carbon and sulfate dynamics along a toposequence of coastal salt marsh soils. The soil at the top end of the salt marsh was salic silty to clayic Typic Sulfaquent (Salzrohmarsh) and the bottom end was sandy to silty Haplic Sulfaquent (Übergangsmischwatt). The mean (depth: 0-100 cm) values of $\mathrm{pH}$ and $\mathrm{rH}$ were $6.8-6.9 ; 6.8-7.0$ and 17.3-8.1; $15-8.6$ for the Typic Sulfaquent (TS) and Haplic Sulfaquent (HS) throughout the year, respectively. The net-emission of $\mathrm{CO}_{2}$ was negative $\left(-14.0 \mathrm{~g} \mathrm{~m}^{-2} \mathrm{yr}^{-1}\right)$ for the $\mathrm{HS}$ but highly positive $\left(857 \mathrm{~g} \mathrm{~m}^{-2} \mathrm{yr}^{-1}\right)$ for the TS throughout the year. The annual emissions of $\mathrm{CH}_{4}$ were almost 10 fold higher in HS $\left(0.3 \mathrm{~g} \mathrm{~m}^{-2} \mathrm{yr}^{-1}\right)$ than that of the TS $\left(0.03 \mathrm{~g} \mathrm{~m}^{-2} \mathrm{yr}^{-1}\right)$. The concentrations of $\mathrm{CH}_{4}$ at different seasons showed almost inverse relationships with the concentrations of $\mathrm{CO}_{2}$, varied significantly $(\mathrm{p} \leq 0.05)$ with the seasons and depth function, and showed no dependence to temperature. The $\mathrm{SO}_{4}$ contents were observed maximum in the TS than that of HS during all the seasons. There was no noticeable correlation $(\mathrm{r}=-$ 0.09) between $\mathrm{SO}_{4}$ and $\mathrm{CH}_{4}$ concentrations. Moreover, even $\mathrm{CH}_{4}$ was determined at depths where the $\mathrm{SO}_{4}$ concentration was about $1200 \mathrm{mg} \mathrm{SO}_{4} \mathrm{~L}^{-1}$. @JASEM
\end{abstract}

Trace gases are becoming more and more interesting due to their possible contribution to an enhance greenhouse effects and global warming. The abundance of $\mathrm{CH}_{4}$ has increased by $150 \%$ to 1.74 ppm and $\mathrm{CO}_{2}$ by $31 \%$ to $367 \mathrm{ppm}$ (IPCC, 2001 ) in the atmosphere since 1750. Methane contributes approximately $25 \%$ of global warming and closer to $10 \%$ of annual global emission and masks the mitigation potential induced by the reduction in $\mathrm{CO}_{2}-\mathrm{C}$ emission ( $\mathrm{Mu}$ et al., 2006). Soils are major global sources and sinks of methane and play an important role in regulating atmospheric $\mathrm{CH}_{4}$ (Nakano et al., 2006). The fluxes of carbon from soil are an important part of the terrestrial carbon budget and the global carbon cycle. Coastal soils are emittants of $\mathrm{CH}_{4}$ besides $\mathrm{CO}_{2}$ due to having the oxidation-reduction processes as a result of frequent tidal influences but the extend of those fluxes to atmosphere is not yet clear.

There were large $\mathrm{CH}_{4}$ concentrations in salting and in sulfate enriched hyper saline environments (Giani et al., 1996). Moreover, as soils differ in their characteristics, it is expected that soil $\mathrm{CO}_{2}$ and $\mathrm{CH}_{4}$ emissions also differ according to particular properties of the soils. Carbon dioxide develops under oxic as well as under anoxic soil conditions, while methane is produced in anaerobic environments through either $\mathrm{CO}_{2}$ reduction. It is obvious that the factors affecting $\mathrm{CH}_{4}$ and $\mathrm{CO}_{2}$ emissions are complicated and interrelated.
The redox potentials of less than $-200 \mathrm{mV}$ are the favorable condition for $\mathrm{CH}_{4}$ formation (Conrad, 1989). On the other hand, Holmer and Kristensen (1994) suggested that there is a coexistence of sulfate reducing and methane producing bacteria. Coastal salt marsh soils have high $\mathrm{CH}_{4}$ concentration despite of the higher $\mathrm{SO}_{4}$, play an important role in sequestration of carbon and emissions of trace gases (Schipper and Reddy, 1994). Investigations on the sources, sinks and factors regarding the trace gas emissions and their concentrations throughout the soil profiles especially in coastal or young marine soils are still insufficient. Accordingly, this investigation was done to evaluate the sources and sinks strength, and factors regulating the fluxes of carbon and sulfate dynamic in the coastal salt marsh soils of Northern Germany.

\section{MATERIALS AND METHODS}

Field study was conducted at Soenke-Nissen-Koog in Schleswig-Holstein of Kiel in Germany during 2000-2001. The possible factors (Table 1) controlling the parameters regarding $\mathrm{C}$-dynamics along a toposequence of daily to seasonally flooded coastal salt marsh soils were studied. The toposequence of the site is divided into two sectors (Table 1). The soil at the top end of the salt marsh was classified as salic silty to clayic Typic Sulfaquent (Salzrohmarsh), which is flooded (with a height of $1.8 \mathrm{~m}$ above sea level: a.s.1. or $0.15 \mathrm{~m}$ above mean high tide) for about 180 times in a year. This sector is covered with small $(3-20 \mathrm{~cm})$ vegetation (Puccinellia maritima along with some 
Halophytes), which is extensively grazed by sheep during summer. While the soil at the bottom end of the site is flooded $(1.4 \mathrm{~m}$ a.s.l. or $0.25 \mathrm{~m}$ below mean high tide) for about 700 times in a year and the vegetations were mainly Spartina anglica and Salicornia europea. The soil in this section was classified as sandy to silty Haplic Sulfaquent (Übergangsmischwatt: Table 1).

Emissions of $\mathrm{CO}_{2}$ and $\mathrm{CH}_{4}$ from the surfaces of soils were measured in each month starting from May to October of the year. The data are presented based on the different seasons prevailing during May (Spring), June (Summer), August (Autumn) and September (Winter) of the year. The samples were collected from six spots as replications and then analyzed following chamber (made by acrylic glass with a base of $990 \mathrm{~cm}^{2}$ and a content of $27 \mathrm{~L}$ ) method (Hutchinson and Mosier, 1981). Concentrations of $\mathrm{CO}_{2}$ and $\mathrm{CH}_{4}$ in the soils and distribution of $\mathrm{SO}_{4}$ were investigated at different depths of the soil profiles by using aluminum-tube with a diameter of $10 \mathrm{~cm}$. The tubes were installed by pressing (somewhere drilling) towards the depths of about $100 \mathrm{~cm}$ as required leaving no space inside the tube. The soil monolith inside the Al-tube was sectioned at every $10 \mathrm{~cm}$ and the process of evacuation then collected the gases through a $100 \mathrm{~mL}$ syringe. The gas samples were analyzed with a Gas Chromatograph (Shimadzu GC-14 with LC10) equipped with FID and ECD. The $\mathrm{SO}_{4}$ concentration was determined by the $\mathrm{BaCl}_{2}$ method. Temperature sensors measured soil temperatures during 2000-2001 and mean annual temperature was determined from this measurement. The redox potentials were determined with stationary platinum electrodes against $\mathrm{Ag} / \mathrm{AgCl}$-electrodes at different depths of the studied soils.

\section{RESULTS AND DISCUSSION}

Redox potential and Soil temperature: The mean values of redox potentials (Eh) in the Typic Sulfaquent (TS) were ranged from -66 to +104 and were negative towards the deeper depth during all the seasons, except for the surface soils during summer, where the mean value was $+104 \mathrm{mV}$ (Table not shown). The standard deviations (SD) were also varied widely, especially summer and autumn. Mostly the Eh in the upper $3 \mathrm{~cm}$ of the surface soils of Haplic Sulfaquent (HS) were varied from 12 to $33 \mathrm{mV}$. The Eh values in the subsoils $(50-100 \mathrm{~cm})$ of both the TS and HS indicated that the methanogenesis can be occurred in the soils. The $\mathrm{rH}$ values (Table 1) in the epipedon of the HS and TS were ranged from 14.4 to 17.3 (corresponding with a grayish green to olive color of the soil matrix together with reddish brown holes), and in the sub-soils from 8.1 to 11.9 (corresponding with a black soil color due to sulfide). The $\mathrm{rH}$ values $<13$ normally corresponds with a black color due to the formation of sulfide, and values $<10$ make possible methane formation, whereas the values in between $13-20, \mathrm{Fe}^{3+}$ can be reduced and FeII/FeIII oxides led to the formation of so called blue green rust, together with reddish brown ferrihydrite along holes of soil animals and plant roots. In the present study more than $500 \mathrm{mg}$ $\mathrm{SO}_{4} \mathrm{~kg}^{-1}$ were determined in the surface soils of all the profiles in different seasons (Fig. 1), which might be due to the frequent addition of $\mathrm{SO}_{4}$ from the highly $\mathrm{SO}_{4}$ enriched sea waters. The $\mathrm{rH}$ values of the soils were found to have maintained the established relationships (Schlichting et al., 1995) of $\mathrm{CH}_{4}$ productions and/or concentrations and emissions of the soils as reflected by figure 1 and table 2.

Table 1: Selected physico-chemical properties of salt marsh soils at the Wadden sea coast of North Germany.Typic Sulfaquent (Typishe Salzrohmarsh): Vegetation - Puccinellia maritima along with some Halophytes, about 180 flooding per year, strongly stratified.

\begin{tabular}{|c|c|c|c|c|c|c|c|c|}
\hline $\begin{array}{l}\text { Depth } \\
\text { (cm) }\end{array}$ & $\begin{array}{l}\text { Horizon } \\
\text { (US Tax.) }\end{array}$ & $\mathrm{rH}^{\#}$ value & $\begin{array}{c}\mathrm{pH} \text { water } \\
(1: 2.5)\end{array}$ & $\begin{array}{c}* \mathrm{ECe} \\
\left(\mathrm{mS} \mathrm{cm}^{-1}\right)\end{array}$ & $\begin{array}{l}\text { Org.-C } \\
\left(\mathrm{g} \mathrm{kg}^{-1}\right)\end{array}$ & $\begin{array}{l}\text { Total-N } \\
\left(\mathrm{g} \mathrm{kg}^{-1}\right)\end{array}$ & $\begin{array}{l}\text { Bulk density } \\
\left(\mathrm{Mg} \mathrm{m}^{-3}\right)\end{array}$ & $\begin{array}{l}\text { Hydrolic } \\
\text { con. }\left(\mathrm{cm} \mathrm{d}^{-1}\right)\end{array}$ \\
\hline $0-14$ & Azh & $17.3-10.4$ & 6.9 & 37.1 & 35 & 3.8 & 0.73 & 70.8 \\
\hline $14-29$ & Czrg & & 6.9 & 36.9 & 27 & 2.8 & 0.81 & 47.2 \\
\hline $29-45$ & Czgr & & 6.9 & 40.7 & 23 & 2.4 & 0.79 & 48.5 \\
\hline $45-70$ & Czr1 & $11.8-8.8$ & 6.8 & 38.3 & 21 & 2.1 & 0.80 & 1.0 \\
\hline $70-120$ & Czr2 & $10.7-8.1$ & 6.8 & 39.7 & 18 & 1.8 & 0.76 & 0.4 \\
\hline \multirow[t]{2}{*}{ Depth } & \multicolumn{3}{|c|}{ Particle size (Int.) distribution (\%) } & CEC & \multicolumn{4}{|c|}{ Water content $(\%)$ at different $\mathrm{pF}$ values } \\
\hline & Sand & Silt & Clay & $\mathrm{c} \mathrm{mol} \mathrm{kg}^{-1}$ & $-\infty$ & 1.8 & 2.5 & 4.2 \\
\hline $0-14$ & 7.6 & 66.2 & 26.2 & 24.4 & 70.6 & 54.5 & 48.3 & 32.4 \\
\hline $14-29$ & 7.5 & 65.0 & 27.5 & 27.7 & 67.7 & 59.1 & 50.9 & 28.7 \\
\hline $29-45$ & 8.1 & 63.8 & 28.1 & 24.4 & 68.7 & 60.8 & 52.8 & 26.4 \\
\hline $45-70$ & 5.0 & 62.8 & 32.2 & 21.5 & 68.6 & 63.6 & 55.0 & 25.7 \\
\hline $70-120$ & 39.9 & 27.6 & 32.5 & 21.6 & 70.4 & 63.3 & 54.3 & 26.3 \\
\hline
\end{tabular}


Haplic Sulfaquent (Marines Übergangsmischwatt): Vegetation - Spartina anglica and Salicornia europea, about 600 flooding per year, strongly stratified.

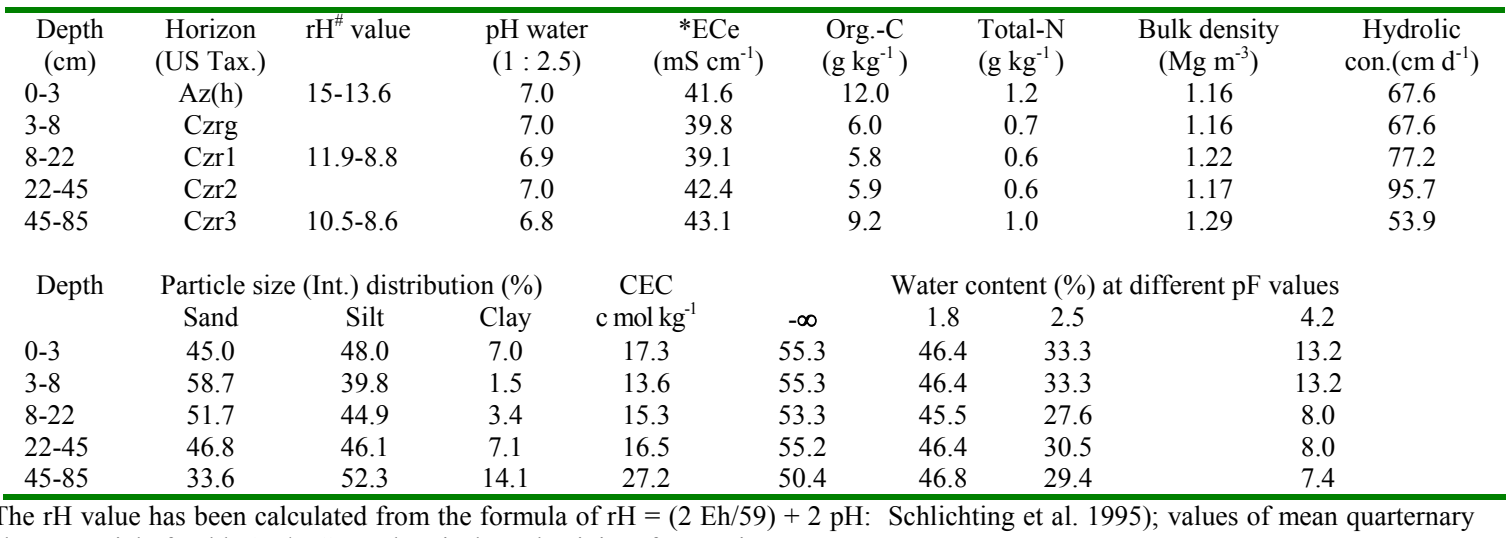
redox potential of Table $2{ }^{*} \mathrm{ECe}=$ Electrical conductivity of saturation extracts.

The mean values of soil temperatures were in the range of 9.0 to $9.8^{\circ} \mathrm{C}$ for TS at depths of 0 to 100 $\mathrm{cm}$ and 10.1 to $12.0^{\circ} \mathrm{C}$ for $\mathrm{HS}$ at depths of 0 to 50 $\mathrm{cm}$ throughout the year (Table 2). The higher temperatures at the later especially during summer seem to be influenced by daily flooding with relatively warmer seawater. The soil temperatures were almost $2^{\circ} \mathrm{C}$ higher in HS than that of the TS and it was also $2.5^{\circ} \mathrm{C}$ higher than the mean annual temperature of the soils $\left(9.5^{\circ} \mathrm{C}\right)$, which might be due to higher absorption of solar radiation by the almost bare and more salt saturated surface of the HS soil and by the warmer surface sea water intrusions. The similar trend of increment of mean annual soil temperature was also observed for the soils of the National park in Schleswig-Holstein (Becker, 1998).

Emissions of $\mathrm{CO}_{2}$ : The net emissions of $\mathrm{CO}_{2}(-14.0$ $\mathrm{g} \mathrm{m}^{-2} \mathrm{yr}^{-1}$ ) were obtained negative (Table 3 ) for HS, except for the summer. These negative values of $\mathrm{CO}_{2}$ emissions were might be due to rapid growth and development of vegetations together with high translocation of emitted $\mathrm{CO}_{2}$ by seawater. But in TS, the emissions of $\mathrm{CO}_{2}$ were highly positive throughout the year $\left(857 \mathrm{~g} \mathrm{~m}^{-2} \mathrm{yr}^{-1}\right)$ in comparison to the HS $\left(-14.0 \mathrm{~g} \mathrm{~m}^{-2} \mathrm{yr}^{-1}\right)$, which might be due to high temperature, less flooding and the extremely low vegetation cover as well as the activities of both micro flora and fauna, soil physical parameters, etc. of the salt marsh soils. The present findings of $\mathrm{CO}_{2}$ emissions can be compared with the results of Scala et al. (2000) who measured $\mathrm{CO}_{2}$ emissions ranged from 137 to $3455 \mathrm{~g} \mathrm{~m}^{-2} \mathrm{yr}^{-1}$ during November, 1998. Howard and Howard (1993) also proved that the emissions of $\mathrm{CO}_{2}$ strongly depend on soil temperature and water content.

Table 2: Mean seasonal and calculated annual net emissions $\left(\mathrm{mg} \mathrm{m}^{-2} \mathrm{~h}^{-1}\right)$ of $\mathrm{CO}_{2}$ and $\mathrm{CH}_{4}$ from salt marsh soils in the Wadden sea coast of Northern Germany.

\begin{tabular}{|c|c|c|c|c|c|c|c|c|c|c|c|}
\hline \multirow[b]{2}{*}{ Soil unit } & \multicolumn{2}{|c|}{ Spring } & \multicolumn{2}{|c|}{ Summer } & \multicolumn{2}{|c|}{ Autumn } & \multicolumn{2}{|c|}{ Winter } & \multicolumn{3}{|c|}{ Emission rates } \\
\hline & \multicolumn{2}{|c|}{ SD } & \multirow{2}{*}{\multicolumn{2}{|c|}{ SD }} & \multirow{2}{*}{\multicolumn{2}{|c|}{$\mathrm{SD}$}} & \multicolumn{2}{|c|}{$\mathrm{SD}$} & \multirow{2}{*}{\multicolumn{2}{|c|}{$\mathrm{mg} \mathrm{m}^{-2} \mathrm{~d}^{-1}$}} & \multirow[t]{2}{*}{$\mathrm{g} \mathrm{m}^{-2} \mathrm{yr}^{-1}$} \\
\hline \multicolumn{5}{|c|}{ Emissions of $\mathrm{CO}_{2}\left(\mathrm{mg} \mathrm{m}^{-2} \mathrm{~h}^{-1}\right)$} & & & & & & & \\
\hline Haplic Sulfaquent & -3.19 & 55 & 7.7 & 102 & -2.0 & 56 & -8.9 & 26 & -38 & 8.4 & -14.0 \\
\hline Typic Sulfaquent & 33.6 & 93 & 116 & 193 & 196 & 234 & 45.5 & 86 & 23 & & 857 \\
\hline \multicolumn{12}{|c|}{ Emissions of $\mathrm{CH}_{4}\left(\mu \mathrm{g} \mathrm{m}^{-2} \mathrm{~h}^{-1)}\right.$} \\
\hline Haplic Sulfaquent & -3.36 & 67 & 24.9 & 41 & 67.7 & 147 & 47.1 & 131 & 0.8 & & 0.3 \\
\hline Typic Sulfaquent & -5.7 & 59 & 8.8 & 27 & 18.3 & 29 & -6.2 & 70 & 0.0 & & 0.03 \\
\hline \multicolumn{12}{|c|}{ Level of Significance: } \\
\hline \multirow[t]{3}{*}{ U-Test } & \multicolumn{4}{|c|}{ Haplic Sulfaquent } & \multicolumn{7}{|c|}{ Typic Sulfaquent } \\
\hline & Spring & & Summ & & Autun & & Sprin & & Summer & & Autumn \\
\hline & $\begin{array}{l}\mathrm{CO}_{2} \\
0.190\end{array}$ & $\begin{array}{l}\mathrm{CH}_{4} \\
2.203 * *\end{array}$ & $\mathrm{CO}_{2}$ & $\mathrm{CH}_{4}$ & $\mathrm{CO}_{2}$ & $\mathrm{CH}_{4}$ & $\begin{array}{l}\mathrm{CO}_{2} \\
1.65\end{array}$ & $\begin{array}{l}\mathrm{CH}_{4} \\
\quad 1.687^{*}\end{array}$ & $\mathrm{CO}_{2} \mathrm{CH}$ & & $\mathrm{CO}_{2} \mathrm{CH}_{4}$ \\
\hline Autumn & 0.468 & 1.137 & 0.158 & 0.574 & & & 3.193 & ** 2.328** & 1.507 & 1.240 & \\
\hline Winter & 0.350 & $1.850^{*}$ & 0.008 & $1.957^{*}$ & 0.516 & 0.428 & 0.771 & 0.231 & 0.741 & 0.824 & $\begin{array}{c}2.494 * * \\
1.703 *\end{array}$ \\
\hline
\end{tabular}



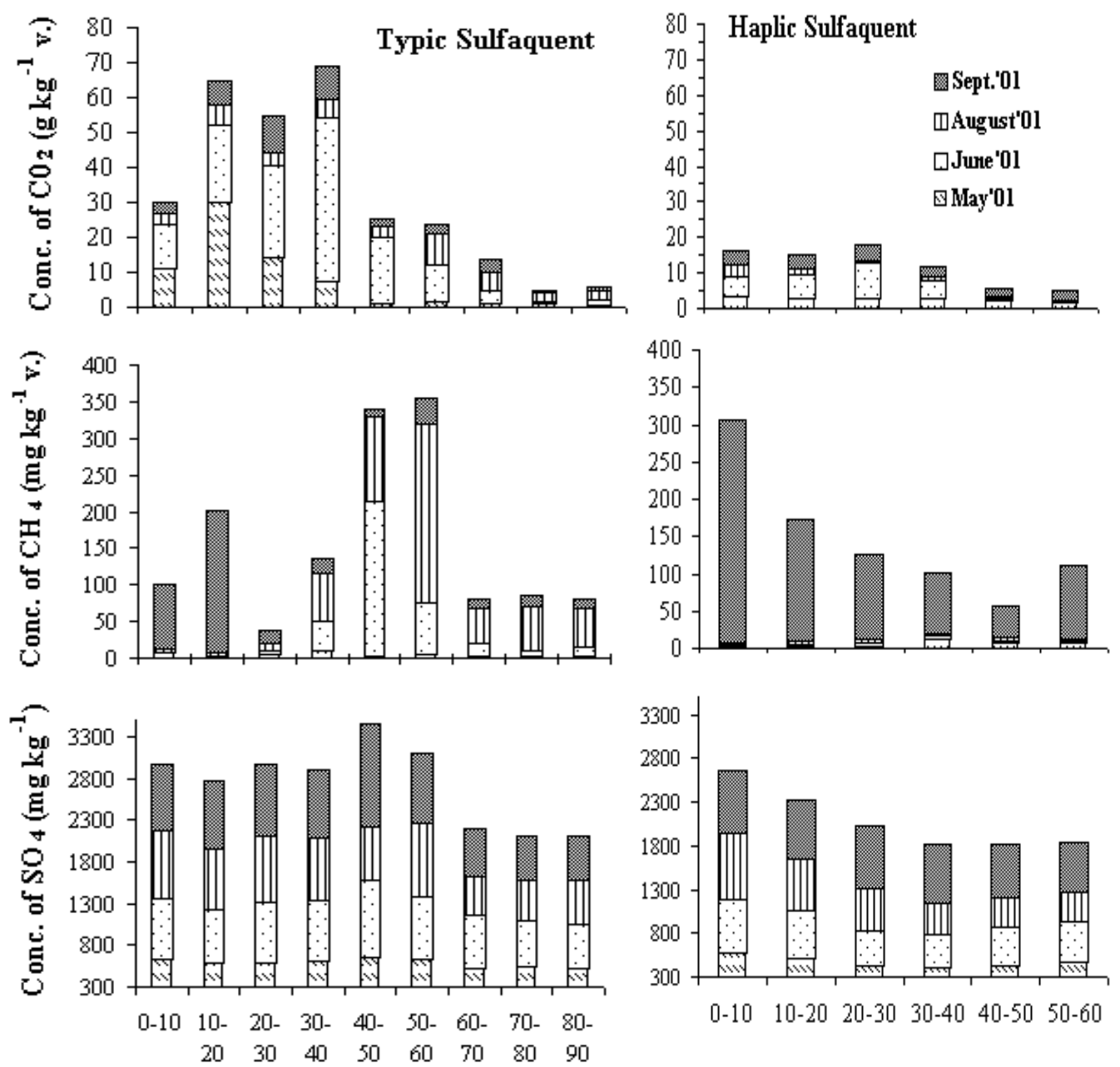

Fig. 1. Seasonal distribution of $\mathrm{CO}_{2}, \mathrm{CH}_{4}$ and $\mathrm{SO}_{4}$ in salt-marsh soils of North Germany

Emissions of $\mathrm{CH}_{4}$ : The annual emissions of $\mathrm{CH}_{4}$ were almost 10 folds higher $\left(0.3 \mathrm{~g} \mathrm{~m}^{-2} \mathrm{yr}^{-1}\right)$ in HS than that $\left(0.03 \mathrm{~g} \mathrm{~m}^{-2} \mathrm{yr}^{-1}\right)$ of the TS (Table 3). Methane emission rates varied seasonally, with the greatest in autumn and smallest in spring. The small mean efflux in both the soils during summer was probably due to dry weather, which favors oxidation of $\mathrm{CH}_{4}$ during its movement from the subsoil to the topsoil. Biological activity was diminished due to low temperature during spring, which results the lowest emissions, while the emissions were increased during summer months of August and September. These increased emissions were not only caused by the higher temperature enhancing more bacterial productivity but also by the high transpiration rate with a direct efflux of $\mathrm{CH}_{4}$ from the roots to the atmosphere
(Sebacher et al., 1985). Cracks in the soil as well as the loss of oxygen in the rhizosphere due to transport of air via aerenchyms enhances the oxidation. The increased rate of $\mathrm{CH}_{4}$ may be compensated by stronger oxidation in summer and that might be the reason for the moderate variations in emissions of $\mathrm{CH}_{4}$ between the seasons. The increased emissions of $\mathrm{CH}_{4}$ during autumn reflects either the increased transpiration rates during these (August-September) months with plant enforced emission of $\mathrm{CH}_{4}$ or the higher efflux has caused by cracks developed during summer, especially TS soil. The seasonal fluctuations of the $\mathrm{CH}_{4}$ emissions were strongly significant for the HS, while the emissions of $\mathrm{CO}_{2}$ were highly significant for the TS soil (Table 3). These suggest that vegetation cover; activities of soil flora, fauna, soil 
temperature and organic matter status are the considerable controlling factors for these trace gases. The $\mathrm{CH}_{4}$ emission rates during spring and winter were negative for TS, indicating that there was inconsiderable $\mathrm{CH}_{4}$ efflux from these marsh soils. Despite of the potentials of $\mathrm{CH}_{4}$ production according to reduction and content of soil organic matter (Table 1), the emissions of $\mathrm{CH}_{4}$ were low (Table 3), which might be due to strong reducing effect of seawater $\mathrm{SO}_{4}^{-2}$.

Distributions of $\mathrm{CO}_{2}$ : The concentrations of $\mathrm{CO}_{2}$ varied strikingly throughout the soil profiles and also with the seasons of the year. The maximum concentrations of $\mathrm{CO}_{2}$ were measured during June'01 (16.1 $\mathrm{g} \mathrm{kg}^{-1}$ soil v.) followed by May'01 (7.4 g), Sept.'01 (4.5 g) and August'01 (4.4 g) in the TS Soil. But the sequences of concentrations of $\mathrm{CO}_{2}$ were June'01 (4.8) > Sept.'01 (3.3) > May'01 (2.1) > August'01 (1.3 $\left.\mathrm{g} \mathrm{kg}^{-1}\right)$ for the HS soil and May'01 (2.2) > Sept.'01 (1.4 g) for HS soil. However, the maximum concentrations of $\mathrm{CO}_{2}$ were detected within the surface soils of 20 to 40 $\mathrm{cm}$ in both the profiles regardless of the seasons, except for the August'01 where the maximum concentration was measured at a depth of 50 to 60 $\mathrm{cm}$ of the profile of TS soil. The high concentration of $\mathrm{CO}_{2}$ in the TS soil might be the results of dissimilation processes of the plants as well as the higher activities of soil organisms. On the other hand, the stronger tidal influences at the HS soils lead to dissolution of produced $\mathrm{CO}_{2}$ and thereby can be considered as a sink of $\mathrm{CO}_{2}$. Partial water saturation of the soil leads to low air conductivity, which concentrated the gases in the soil air and soil solutions. The low $\mathrm{CO}_{2}$ concentrations in the reduced subsoil of all the soil profiles reflect the low microbial activity.

Distributions of $\mathrm{CH}_{4}$ : The concentrations of $\mathrm{CH}_{4}$ were distributed irregularly with the seasons and soil depths (Fig. 1). In the TS soil, the concentrations of $\mathrm{CH}_{4}$ were measured maximum of $9 \mathrm{mg} \mathrm{kg}^{-1}$ at depths of 30-40 $\mathrm{cm}$ followed by $7 \mathrm{mg}$ at depth of $0-10 \mathrm{~cm}>5 \mathrm{mg}$ at depth of $50-60 \mathrm{~cm}$ during May'01. During June'01, the $\mathrm{CH}_{4}$ concentration was $212 \mathrm{mg}$ at depth of $40-50 \mathrm{~cm}$ followed by $71 \mathrm{mg}$ at depths of $50-60 \mathrm{~cm}>40 \mathrm{mg}$ at depth of $30-40 \mathrm{~cm}$. The $\mathrm{CH}_{4}$ concentrations of $245 \mathrm{mg}$ at depth of $50-60 \mathrm{~cm}>114 \mathrm{mg}$ at depth of $40-50 \mathrm{~cm}>65 \mathrm{mg}$ at $30-40 \mathrm{~cm}$ were measured during August'01. The concentrations of $\mathrm{CH}_{4}$ of $193 \mathrm{mg}$ at depth of $10-20 \mathrm{~cm}>87 \mathrm{mg}$ at $0-10 \mathrm{~cm}>$ $34 \mathrm{mg} \mathrm{kg}$ at $50-60 \mathrm{~cm}$ were detected during September'01 (Fig. 1). The sequences of concentrations of $\mathrm{CH}_{4}$ as measured were August $>$
September $>$ June $>$ May for TS profiles; September $>$ May $>$ August $>$ June for the profiles of HS. The concentrations of $\mathrm{CH}_{4}$ at different seasons showed almost inverse relationships with the concentrations of $\mathrm{CO}_{2}$. In all the profiles, the concentrations of $\mathrm{CH}_{4}$ were very low and varied significantly $(\mathrm{p} \leq 0.05)$ varied with the seasons and soil depths. The concentrations of $\mathrm{CH}_{4}$ showed no dependence to temperature.

High temporal and spatial variations in both the $\mathrm{CO}_{2}$ and $\mathrm{CH}_{4}$ emissions led to question whether are the emission pattern reflects the concentrations of these gases in the soil? The highest concentrations at each sampling times (up to 245 ppmv $\mathrm{CH}_{4}$ ) were found in the TS soil and the lowest concentrations (till $1.4 \mathrm{ppm}$ by volume) were in the HS soil, which were almost in the range of atmospheric concentration $\left(\mathrm{CH}_{4}: 1.65 \mathrm{ppmv}\right)$. Water saturation and/or daily tides dilute the gases in HS soils resulting high gas concentrations to that of the TS, which mean not to build up. Stratification, aggregation and/or variable pore volume with different continuity may lead to an inhomogeneous soil with the formation of traps where produced $\mathrm{CH}_{4}$ is accumulated leading to discontinuous release by bubbling (Takai and Wada, 1990). In the permanent saturated soils, tidal marine water mixes and dilutes the gas content in the soil solution twice a day. Therefore, the Haplic Sulfaquents have comparatively high gas concentrations to that of the Typic Sulfaquent, which mean not to build up. In the Haplic Sulfaquent soil, the shifting water table at rising tide may press $\mathrm{CH}_{4}$ loaded water upward without exporting the soil solution from the system as the hydraulic conductivity of 68 to $96 \mathrm{~cm}$ $\mathrm{d}^{-1}$ in the upper soil which is much lower than the rising tide, leading to an enclosure of the entrapped soil solution. The $\mathrm{SO}_{4}$ concentrations in the studied soil solutions were a few folds higher (Fig. 1) than that of the seawater indicating a low exchange rate between the soil solutions and marine water.

Methane oxidation mediated mainly by methanotrophic bacteria is the responsible process, which is strongly inhibited by ammonium accessible for nitrification (Hütsch, 2001). Indeed, in many studies $\mathrm{NH}_{4}$ was identified as a strong inhibitor for $\mathrm{CH}_{4}$ oxidation (Bronson and Mosier, 1994). Root derived organic $C$ can contribute to various $\mathrm{C}$ pools and become an origin of $\mathrm{CH}_{4}$ emitted from flooded soils (Lu et al., 2000). In the total amount of atmospheric $\mathrm{CH}_{4}$, the contribution of $\mathrm{CH}_{4}$ from sulfate-rich soils is negligible, because sulfate-reducing and methane producing organisms compete for the same substrates 
$\left(\mathrm{H}_{2} / \mathrm{CO}_{2}\right.$, acetate-competitive substrates) but the sulfate reducers have the competitive advantage: they have stronger affinity to the competitive substrates and can use them to provide more energy than the methane producers (Schönheit et al., 1982). Increasing methane and decreasing sulfate concentrations (methane-sulfate transition) are found in some deeper depths, but not consistent with the seasons. Most of the soils contained more $\mathrm{CH}_{4}$ in August-September than those of May-June, indicating no methane-sulfate transition, which means sulfate reduction is not limited and methanogenesis is suppressed down to that depth. As methanogenesis is strictly anaerobic, more $\mathrm{CH}_{4}$ was expected in the more anaerobic soils. The soils under more anaerobic condition (near the sea) did not contain maximum methane nor did the more aerobic soil (far away from the sea) contain the least. This suggesting that there seemed to be no relation between methane concentration and state of soil development. There was also no evident relation between the redox properties and their corresponding methane concentrations.

Distributions of $\mathrm{SO}_{4}$ : There should be high $\mathrm{SO}_{4}$ contents in the surface soils, which might be reduced to sulfide at subsoils. But in reality, the high $\mathrm{SO}_{4}$ were determined in the subsoils of all the profiles in different seasons at depths of $40-50 \mathrm{~cm}$ followed by surface soils of TS (Fig. 1). The $\mathrm{SO}_{4}$ contents were obtained maximum (up to $1236 \mathrm{mg}$ $\mathrm{kg}^{-1}$ ) in the TS followed by HS (up to $745 \mathrm{mg}$ ) during all the seasons (Fig. 1), which was due to the result of the frequent intrusion of highly $\mathrm{SO}_{4}(>$ $600 \mathrm{mg} \quad \mathrm{SO}_{4} \mathrm{~L}^{-1}$ ) enriched seawaters. The concentrations of $\mathrm{SO}_{4}$ throughout the profiles of all the soils were quite inversely distributed in relation to $\mathrm{CH}_{4}$ concentrations throughout the year, except for the depths of 40-50 cm during June'01 and 50$60 \mathrm{~cm}$ during August'01 for the TS profile where both the $\mathrm{CH}_{4}$ and $\mathrm{SO}_{4}$ contents were high. These indicate that there may be a coexistence of sulfate reducing and methane producing bacteria as reported by Holmer and Kristensen (1994). There is no noticeable correlation $(\mathrm{r}=-0.09)$ was obtained between the $\mathrm{SO}_{4}$ and $\mathrm{CH}_{4}$ concentrations. Moreover, even $\mathrm{CH}_{4}$ was determined at depths where the $\mathrm{SO}_{4}$ concentrations were around 1200 mg $\mathrm{SO}_{4} \mathrm{~L}^{-1}$. This indicates that either $\mathrm{CH}_{4}$ production is compatible even with the higher $\mathrm{SO}_{4}$ concentration.

The present findings concluded that the fluxes of $\mathrm{CO}_{2}$ and $\mathrm{CH}_{4}$ from the coastal salt-marsh soils varied remarkably among the seasons and may act either as a sink or source of atmosphere depending on the nature of the soils. Relatively high net emission of $\mathrm{CO}_{2}$ was determined from the Typic Sulfaquent under salt meadow. The $\mathrm{CH}_{4}$ emission was low resulting from low formation of $\mathrm{CH}_{4}$, which was due to a high $\mathrm{SO}_{4}$ input from $\mathrm{SO}_{4}$ enriched seawater. There was also no significant concentration/efflux of $\mathrm{CH}_{4}$, suggesting almost no contribution from the studied coastal salt marsh soils to the atmospheric methane. The heterogeneity in redox potential of the soils studied also indicate that $\mathrm{CH}_{4}$ oxidation is likely to take place, and the $\mathrm{CH}_{4}$ emission and concentration gradients suggest that the $\mathrm{CH}_{4}$ produced is readily oxidized within the soils. Vegetation cover, temperature and organic matter status are the considerable controlling factors for these trace gases. Further research should be focused on more detailed look on the geophysical conditions of the soils, and $\mathrm{CH}_{4}$ oxidation and $\mathrm{SO}_{4}$ reduction rates.

Acknowledgement: The senior author Prof. Dr. Md. H. R. Khan (AvH ID: BAN/1013648) gratefully acknowledges the postdoctoral fellowships during the years of 1994-96 and 2001 by the "Alexander von Humboldt Foundation" Germany, which enable him to carry out this research work.

\section{REFERENCES}

Becker, G (1998). Wassertemperaturn. In J. Kohlus and H. Küpper (ed.), Umwelt atlas Wattenmeer. I Nordfriesisches und Dithmarscher Wattenmeer p. 62-63. E. Ulmer, Stuttgart.

Bronson, K F; Mosier, A R (1994). Suppression of methane oxidation in aerobic soil by nitrogen fertilizers, nitrification inhibitors, and urease inhibitors, Biol. Fertile. Soils. 17, 263-268.

Conrad, R (1989). Control of methane production in terrestrial ecosystems. In: Andreae, M.O. and Schimmel, D.S. (Ed.): Exchange of trace gases between terrestrial ecosystems and the atmosphere, J. Wiley and Sons Publisher, pp 39-58.

Giani, L; Dittrick K; Martsfeld-Hartmann A; Peters G (1996). Methanogenesis in salt marsh soils of the North Sea Coast of Germany, Europ. $J$. of Soil Sci., 47, 175-182.

Holmer, M; Kristensen, E (1994). Coexistence of sulfate reduction and methane production in an organic-rich sediment, Marine Ecology, 107, 177-184. 
Howard, D M; Howard P J A (1993). Relationships between $\mathrm{CO} 2$ evolution, moisture content and temperature for a range of soil types, Soil Biology and Biochemistry, 25, 1537-1546.

Hütsch, B W (2001). Methane oxidation, nitrification, and counts of methanotrophic bacteria in soils from a long-term fertilization experiment ("Ewiger Roggenbau" at Halle), $J$. Plant Nutr. Soil Sci., 164, 21-28.

Hutchinson, G L; Misier A R (1981). Improved soil cover method for field measurement of nitrous oxide fluxes, Soil Sci. Soc. Am. J., 45, 311-316.

IPCC, (2001). Climate change 2001. Synthesis Report: Summary for policymakers. http://www.ipcc.ch.

Lu, Y; Wassmann, R; Neue, H U; Huang, C (2000). Dynamics of dissolved organic carbon and methane emissions in a flooded rice soil, Soil Sci. Soc. Am. J., 64, 2011-2015.

Mu, Z; Kimura, S D; Hatano, R (2006). Estimation of global warming potential from upland cropping systems in central Hokkaido, Japan. Soil Science and Plant Nutrition, 52, 371-377.

Nakano, T; Takeuchi, W; Inue, G; Fukuda, M; Yasuoka, Y (2006). Temporal variations in soil-atmosphere methane exchange after fire in a peat swamp forest in West Siberia. Soil Science and Plant Nutrition, 52, 77-88.

Scala Jr., N L; Marques Jr., J; Pereira, G T; Cora, J E (2000). Carbon dioxide emission related to chemical properties of a tropical bare soil, Soil Biology and Biochemistry, 32, 1469-1473.

Schipper, L A; Reddy, K R (1994). Methane production and emissions from four reclaimed and pristine wetlands of Southern United States, Soil Sci. Soc. Am. J., 58, 1270-1275.

Schlichting, E; Blume, H -P; Stahr, K (1995). Boden-Kundliches Praktikum, (2., neubearbeitete Auflage). Blackwell Wissenschafts-Verlag Berlin.

Schönheit, P; Kristjansson, J K; Thauer, R K (1982). Kinetic mechanism for the ability of sulfate reducers to out-compete methanogens for acetate, Archives of Microbiology, 132, 285-288.

Sebacher, D I; Harris, R C; Bartlett, K B (1985). Methane emissions to the atmosphere through aquatic plants, J. Environ. Qual., 14, 40-46.

Takai, Y; Wada, E (1990). Methane formation in waterlogged paddy soils and its controlling factors, In: Scharpenseel , H.W., Schomaker, M. and Ayoub A. (ed.), Soils on warmer earth, Development in Soil Science 20, Elsevier, Amsterdam, 101-107 